\title{
Green Virtual Enterprise Breeding Environment Reference Framework
}

\author{
David Romero and Arturo Molina \\ Tecnológico de Monterrey, México \\ david.romero.diaz@gmail.com, armolina@itesm.mx
}

\begin{abstract}
A Green Virtual Enterprise (GVE) is an emerging sustainable manufacturing and logistics networked enterprise model focused on offering, delivering and recovering green products to/from the market, under a lifecycle thinking and supported by its source network. In this paper, a GVE Breeding Environment Reference Framework is proposed as a common architectural framework offering a clear approach for conceiving sustainable and fully flexible forward and reverse supply networks, within a breeding environment context, based on a set of five building blocks: targets, main actors, operating principles, lifecycle and supporting technologies, to create and manage GVEs.
\end{abstract}

Keywords: Collaborative Networked Organizations, Green Virtual Enterprises, Breeding Environments, Sustainable Supply Networks, Industrial Ecology, Industrial Symbiosis, Sustainable Industrial Development.

\section{Introduction}

The Green Virtual Enterprise phenomenon is nowadays gaining attention worldwide, be it in the form of sustainable supply chains, finding its way as a promising paradigm in manufacturing and service industries to help enterprises to cope with the challenges of turbulent market conditions in the context of economic, environmental and social pressures to achieve a sustainable industrial development model. However, traditional sustainable supply chain practices tend to value innovations that are incremental in nature. As a result, current sustainable supply chain strategies are appropriate to make the supply chain "more sustainable", rather than "fully sustainable", as a fully sustainable approach may require a complete re-engineering of the whole supply chain. In this sense, the Green Virtual Enterprise (GVE) initiative [1] aims a radical value innovation approach as a response to the difficulties of dynamically creating and managing different but integrated flexible forward and reverse supply networks, better known as 'closed-loop supply networks', to address the market dynamic changes and divergent customers' buying behaviour in a sustainable way. By enhancing the traditional sustainable supply chain practices [2] with the dynamic VE principles [3], the GVE Breeding Environment (GVBE) Reference Framework goal is to support the creation and management of short-term and dynamic coalitions of green enterprises, that may be tailored within a GVBE, to respond in a sustainable way to collaboration (business) opportunities, by integrating the green skills or core- 
competencies and resources required to meet or exceed the quality, time and cost frames expected by the customer, striving always the triple bottom line.

In this paper, a GVBE Reference Framework is proposed as a common architectural framework offering a clear approach for conceiving sustainable and fully flexible forward and reverse supply networks, within a breeding environment context, based on a set of five building blocks: targets, main actors, operating principles, lifecycle and supporting technologies, to create and manage GVEs.

\section{Green Virtual Enterprise Breeding Environment Base Concepts}

For a complete understanding of the GVBE Reference Framework building blocks it is important to first define the following base concepts:

Green Enterprise - is an enterprise that strives to meet the triple bottom line by ensuring that all products, processes, manufacturing and logistics activities in its business operation address the sustainable principles [1].

Green competencies - are those environmentally conscious business practices and strategies such as [1]: For forward supply networks: Design for the Environment (DFE), Green Product Lifecycle Management (G-PLM) and Lifecycle Analysis, Lean Manufacturing, Total Quality Environmental Management (TQEM), Environmental Management Systems (EMS), Green Supply Chain Management (G-SCM), Green Logistics, ISO14000 series' requirements. For reverse supply networks: inspection, diagnostic and recondition techniques to obtain the most value from a recovered product through a re-use (e.g. spare parts), refurbish (e.g. repair or re-manufacturing), recycling (e.g. scrap) and/or safe disposal (e.g. hazardous wastes treatments) strategy.

GVE Breeding Environments (GVBEs) - are long-term strategic alliances of green enterprises and their related support institutions aimed at offering the necessary conditions (human, financial, social, infrastructural and organisational) to support the rapid and fluid configuration of GVEs. GVBEs act as closed-loop systems where material, energy, information and technology among their members are recycled or shared to achieve a sustainable efficiency strategy (e.g. industrial symbiosis). GVBEs are intelligent networks for competencies and resources management from different green enterprises aiming to combine their green capabilities and capacities to deploy innovative and cost-effective green technologies and practices to promote a sustainable industrial development through F-GVEs and R-GVEs creation [1] [4] [5].

GVEs as dynamic forward supply networks (F-GVEs) - are temporary alliances of green enterprises that come together in order to better respond the market demands through the most efficient use of their complementary skills or core-competencies and shared resources, for developing and delivering in a sustainable way new products to the customer with a minimal environmental impact - within a GVBE [1] [4] [6].

GVEs as dynamic reverse supply networks (R-GVEs) - are temporary alliances of green enterprises that come together in order to better respond a business opportunity based on a sustainable reverse logistics and end-of-life manufacturing approach for recovering products, parts, subassemblies and/or scrap through the most efficient use of their complementary skills or core-competencies and shared resources for their direct-use (re-use), repair, re-manufacture, recycle or safe disposal - within a GVBE [1]. 


\section{GVE Breeding Environment Reference Framework}

A Green Virtual Enterprise $(G V E)$ is an emerging sustainable manufacturing and logistics networked enterprise model focused on offering, delivering and recovering green products to/from the market, under a lifecycle thinking and supported by its source network. As shown in Fig. 1, the GVBE Reference Framework can be described based on five building blocks to create and manage GVEs in their both modalities: forwards and reverse supply networks.

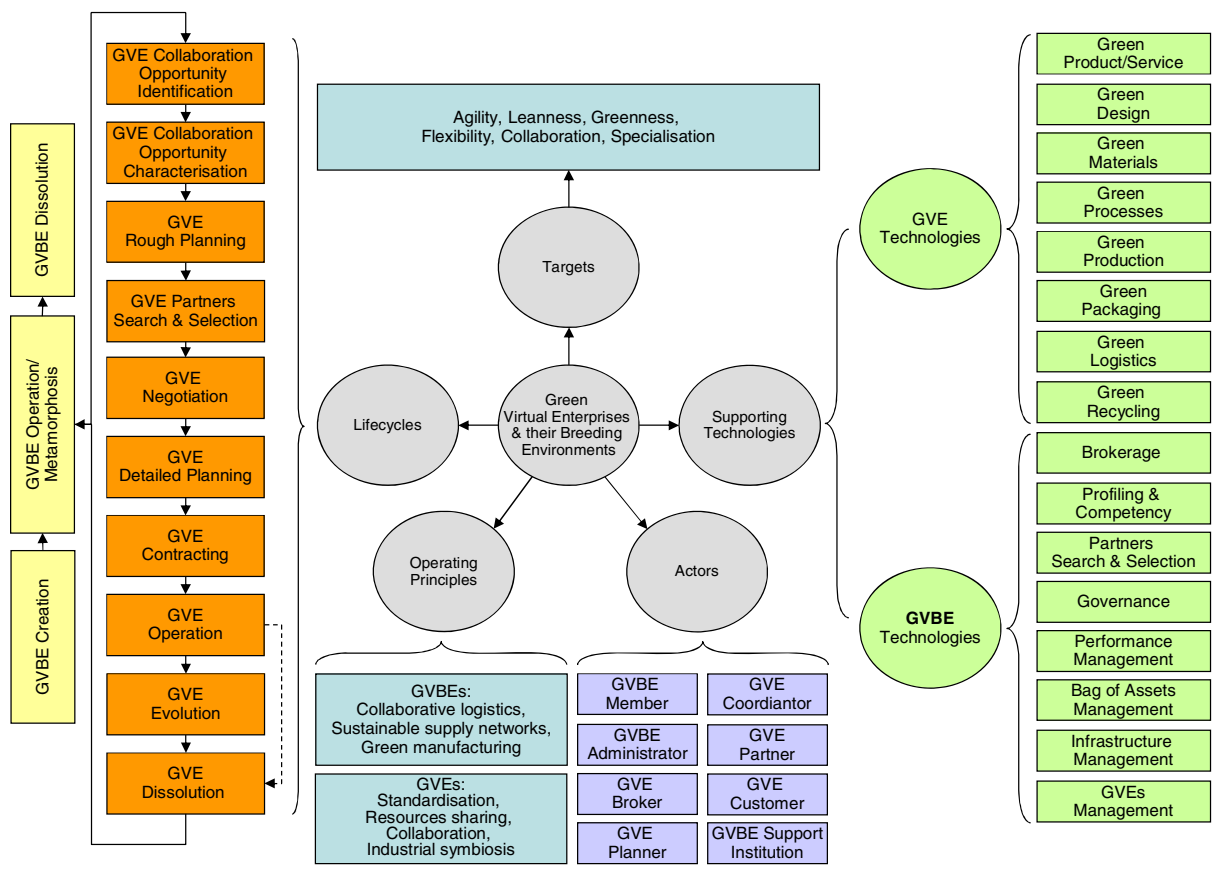

Fig. 1. GVE Breeding Environment Reference Framework

\subsection{GVE Breeding Environment and Green Virtual Enterprises Targets}

The GVBE model potential, to target the achievement of sustainable and fully flexible supply networks, resides in its ability to dynamically configure forward and reverse supply networks (e.g. GVEs), according to the needs and opportunities of the market and keep them operational as long as these opportunities persist, suggesting a number of sustainable benefits, among which the following can be emphasised [see also 3]:

Agility - represented by the ability to react in a short time to a competitive market opportunity through the rapid configuration of a GVE - within a GVBE.

Leanness - represented by the ability to focus on efficiency and lowest cost-to-serve by searching, assessing and selecting the most suitable green enterprises (GVE partners) according to different sustainable quantitative and qualitative metrics [7] in order to reduce production and logistics costs, and environmental impact. 
Greenness - represented by the ability to minimise the environmental impact by integrating different green competencies and technologies available in several green enterprises (GVBE members) within a GVE.

Flexibility - represented by the ability to offer and/or respond with "unlimited" capabilities and capacities to the market demand variations and picks by adding either more green enterprises with complementary competencies to enhance engineering capabilities and/or more green enterprises with the same resources to increase production capacity to a GVE.

Collaboration - represented by the ability to share costs and integrate resources and capabilities from multiple green enterprises in a GVE to exploit collaboration (business) opportunities in the most sustainable way.

Specialisation - represented by the ability to integrate the best green technologies and practices (core-competencies) available in multiple green enterprises in a GVE to offer, deliver and recover green products to/from the market.

\subsection{GVE Breeding Environment and Green Virtual Enterprises Actors}

Eight kinds of actors or stakeholders can be identified within a GVBE and its GVEs, including [5] [8]:

GVBE member - basic role played by a green enterprise registered at the GVBE and ready to participate in the GVBE activities. GVBE members are green enterprises adhering to a base long-term cooperation agreement and to the adoption of sustainable supply chain practices and 'industrial symbiosis' approaches in order to make their individual and collective operations more sustainable by collaborative means.

$G V B E$ administrator - role played by a green enterprise responsible for the overall GVBE operation and evolution from a network management perspective, and from a sustainable industrial development model perspective for the promotion of 'industrial symbiosis partnerships' among the GVBE members by exploring material, energy, information and/or technology flows within the breeding environment that can be used to find resources-based synergies, devise strategies to increase the cycling of resources, and identify gaps in current green competencies and resources management and solve them by searching and recruiting new green enterprises into the GVBE.

GVE broker or simply broker - role played by one or more GVBE members responsible for the identification and acquisition of new collaboration (business) opportunities in the market (e.g. green products development and/or green services provision) by marketing the GVBE green competencies to potential customers, and for the identification and development of new complementary businesses for existing GVBE members' activities or creation of new ones based on core-competencies and resources synergies. GVE brokers should assess each opportunity based on its technical feasibility, economic advantage and environmental impact.

GVE planner or business integrator - role played by a green enterprise responsible for a GVE creation in any of its two modalities: F-GVE or R-GVE. GVE planners are responsible for the identification of the necessary green competencies and capacities, as well as the GVBE members that possess those competencies (potential GVE partners) to deliver and/or recover a green product to/from the market. 
GVE coordinator - role played by a green enterprise responsible for the GVE operation, following the sustainable principles in all its sourcing, production and distribution/logistics activities, in order to achieve the GVE goals in a sustainable way.

GVE partner - basic role played by a green enterprise (GVBE member) involved in a GVE (in any of its two modalities), contributing with its green capabilities and capacities to the GVE goals achievement.

GVE customer - role played by a green consumer that may be an individual or an organisation with an environmental conscious and interested in purchasing green products and/or services from the GVBE by triggering the formation of GVEs.

GVBE support institution or service provider - a green service provider offering complementary services, supporting tools and/or mechanisms to the GVBE, such as: environmental certifications, eco-labels and/or green standards to support the GVBE sustainable industrial model.

\subsection{GVE Breeding Environment and Green Virtual Enterprises Operating Principles}

At GVBE level, some main operating principles to be considered are:

Standardisation - GVBE members will adopt common working and sharing principles, common interoperable infrastructures and a common ontology in order to reduce the barriers towards successful collaborations [8].

Resources sharing - GVBE members will create a resource pool (bag of assets) with different tangible and intangible shared resources in order to eliminate redundant assets within the GVBE and manage their ownership costs in an efficient way [8].

Collaboration - GVBE members will share information, resources, responsibilities, risks and rewards to jointly plan, implement and evaluate sustainable initiatives [9].

Industrial symbiosis - GVBE members will follow a cooperative approach to a sustainable industrial development model and sustainable supply networks involving links/exchanges/sharing of material, energy, information, technology and other tangible and intangible assets and by-products based on a collaboration strategy supported by shared use of assets, logistics, expertise and knowledge transfer [1] [10].

At GVE level, some main operating principles to be considered are:

Collaborative logistics - GVE partners (shippers, carriers and suppliers) will create a green logistics network to reduce the costs and environmental impact related to the transportation of raw materials, components and products by sharing logistics services assets such as trucks, trailers, warehouses and/or containers [11].

Sustainable supply networks - GVE partners will integrate/adopt the sustainability principles into their forward and reverse supply networks, from product design (green designs and green products), to material sourcing and selection (green materials and green suppliers), to manufacturing processes (green production), to the delivery of the final product to the customer (green packaging and green logistics/transportation), as well as into the end-of-life management of the product after its useful life (green recycling) [1] [2].

Green manufacturing - GVE partners will attempt to reduce the environmental impact of their manufacturing activities without sacrificing product quality and cost by focusing on the adoption of those green materials, green processes and green technologies that reduce waste, pollution and energy consumption [12]. 


\subsection{GVE Breeding Environment and Green Virtual Enterprises Lifecycles}

\section{GVBEs lifecycle scenario:}

All GVBEs will go through the following lifecycle stages [1] [5] [8]: (a) creation planning the creation of a new breeding environment by identifying potential areas for eco-industrial networking among the potential GVBE members, defining the GVBE business model targeting specific industry sectors with sustainability benefits and potential GVBE members with a competitive (green) differentiation, and establishing the business processes, (ICT) infrastructures and governance model for populating and launching the GVBE; (b) operation/metamorphosis - GVBEs will operate striving for the diversity of green- enterprises, materials, processes, technologies, products and services that may enhance the industrial symbiosis partnerships within the breeding environment, promoting the creation of truly dynamic and sustainable supply networks (GVEs) offering, delivering and recovering green products and/or services to/from the market, and creating the necessary (common interoperable) infrastructures to facilitate the linking, exchanging and sharing of tangible and intangible assets and by-products as part of the GVBE industrial symbiosis strategy [10] [13]; and (c) dissolution - in the case of a GVBE closing, a knowledge transfer of best practices and lessons learned should be made to other GVBEs (see Table 1).

Table 1. GVBE Detailed Lifecycle Stages [1] [5] [8] [13] [16]

\begin{tabular}{|c|c|c|}
\hline \multicolumn{2}{|c|}{ Lifecycle Stages } & Description \\
\hline \multirow{3}{*}{ 胥 } & \multirow[t]{2}{*}{$\begin{array}{r}\text { Initiation \& } \\
\text { Recruiting }\end{array}$} & $\begin{array}{l}\text { Identification of the potential industry sectors and (green) enterprises that could } \\
\text { be involved in the GVBE. Modelling the GVBE to reveal potential collaboration } \\
\text { (business) opportunities to build-up symbiotic industrial networks (GVEs). } \\
\text { Identification of the infrastructures and support services to be provided } \\
\text { by the GVBE to enable effectiveness and efficient in doing green businesses and } \\
\text { collaborating in industrial symbiosis initiatives. }\end{array}$ \\
\hline & & $\begin{array}{l}\text { Recruitment of the right mix of industries and green enterprises to achieve } \\
\text { a critical mass to create successful industrial symbiosis partnership (GVEs). }\end{array}$ \\
\hline & Foundation & $\begin{array}{l}\text { Establishment and set-up of the business processes, infrastructures and } \\
\text { governance model needed to support the GVBE members' industrial symbiosis } \\
\text { partnerships (GVEs). }\end{array}$ \\
\hline & Operation & $\begin{array}{l}\text { General management of all activities needed to support the GVBE smooth } \\
\text { operation such as: strategic and marketing management; financial, accountability } \\
\text { and resources management; governance management; bag of assets management; } \\
\text { value systems management; ontology management; ICT management; support } \\
\text { institutions management; membership and structure management; profiling and } \\
\text { competency management; trust management; performance management; etc. [16] }\end{array}$ \\
\hline & Metamorphosis & $\begin{array}{l}\text { GVBEs as natural ecosystems, or properly said industrial ecosystems, will adapt } \\
\text { their strategies, business processes and structure to tactically respond to new } \\
\text { sustainable market changes and trends. }\end{array}$ \\
\hline & Dissolution & $\begin{array}{l}\text { If a GVBE may cease to exist, knowledge and technology transfers' initiatives } \\
\text { such be promoted as part of a meta GVBEs' industrial symbiosis network. }\end{array}$ \\
\hline
\end{tabular}

GVEs lifecycle scenarios:

All GVEs, in their forward or reverse supply network modalities, will go through the following lifecycle stages within a breeding environment [1]: (a) creation - a new green business opportunity will be identified (by a GVBE member acting as broker) and will trigger a F-GVE formation for a new green product development or a R-GVE 
formation for a product repair, re-manufacturing, recycling and/or safe disposal; managing both kind of supply networks within a GVBE makes possible to achieve real closed-loop supply networks in any manufacturing industry; (b) operation/ evolution - F-GVEs will operate following sustainable engineering, manufacturing and logistics principles in order to offer and deliver green products to the market, and R-GVEs will operate following sustainable logistics, end-of-life manufacturing and safe disposal principles in order to recover (green) products from the market in order to re-use, re-manufacture, recycle and/or make a safe disposal of them; operating in this way as truly sustainable supply networks supports the journey to a sustainable industrial development model; and (c) dissolution - since F-GVEs and R-GVEs were created within a breeding environment, after the product delivery or recovery, the GVBE will continue with its industrial symbiosis [10] strategy, acting as a closedloop system, in where any surplus and/or abandoned resources/scrap after a F-GVE

Table 2. F-GVE Detailed Lifecycle Stages [1] [6] [14] [15] [16]

\begin{tabular}{|c|c|c|}
\hline \multicolumn{2}{|r|}{ Lifecycle Stages } & Description \\
\hline \multirow{7}{*}{ : } & $\begin{array}{r}\text { Collaboration } \\
\text { Opportunity } \\
\text { Identification }\end{array}$ & $\begin{array}{l}\text { Identification of a collaboration (business) opportunity for manufacturing a } \\
\text { green product and/or offering a green service to a customer. A collaboration } \\
\text { opportunity can be detected by a green broker or promoted as part of the GVBE } \\
\text { strategy to introduce new green products and/or services to the market. }\end{array}$ \\
\hline & $\begin{array}{r}\text { Collaboration } \\
\text { Opportunity } \\
\text { Characterisation }\end{array}$ & $\begin{array}{l}\text { Identification of the main features of the collaboration (business) opportunity, } \\
\text { including the green competency requirements and opportunity constrains: } \\
\text { (a) green product manufacturing - needed green design, materials and process } \\
\text { for designing, engineering and manufacturing a green product or (b) green } \\
\text { service-needed green knowledge and skills to offer a green service. }\end{array}$ \\
\hline & $\begin{array}{r}\text { Rough } \\
\text { Planning }\end{array}$ & $\begin{array}{l}\text { Identification of the required F-GVE partners competencies and capacities, } \\
\text { as well as the F-GVE possible configurations (supply network topologies) } \\
\text { to respond in a sustainable way to a collaboration (business) opportunity. }\end{array}$ \\
\hline & $\begin{array}{r}\text { Partners Search \& } \\
\text { Selection }\end{array}$ & $\begin{array}{l}\text { Identification of the potential F-GVE partners and their assessment and selection } \\
\text { based on their green degree. F-GVE partners will be evaluated based on their } \\
\text { green capabilities (design, materials, processes, technologies and logistics) } \\
\text { to design, produce, supply or distribute a green product or service. }\end{array}$ \\
\hline & Negotiation & $\begin{array}{l}\text { Interactive process to integrate the most suitable F-GVE partners in a dynamic } \\
\text { sustainable supply network to produce and/or offer the required green product } \\
\text { and/or service by the customer or demanded by the market. }\end{array}$ \\
\hline & Detailed Planning & $\begin{array}{l}\text { Definition of the final F-GVE topology and its F-GVE partners' activities } \\
\text { schedule, including tasks assignments, budget allocation and green performance } \\
\text { indicators (clean production and forward logistics). }\end{array}$ \\
\hline & Contracting & $\begin{array}{l}\text { Formulation of the F-GVE contract, paying special attention to the environmental } \\
\text { regulations (laws, trades, taxes, fines). }\end{array}$ \\
\hline & Operation & $\begin{array}{l}\text { F-GVEs will operate following all sustainable principles in order to reduce } \\
\text { the environmental impact of their manufacturing and logistics activities. }\end{array}$ \\
\hline & Evolution & $\begin{array}{l}\text { In case of unexpected events or disruptions during the F-GVE operation, } \\
\text { the F-GVE coordinator will re-configure and/or re-schedule the F-GVE partners } \\
\text { and their activities (tasks, budget) in order to try to keep the original production } \\
\text { and/or offering plan for the promise product and/or service. }\end{array}$ \\
\hline & Dissolution & $\begin{array}{l}\text { As part of the GVBE industrial symbiosis strategy, any resource that could have } \\
\text { a secondary usage will be placed in the GVBE bag of assets for any possible } \\
\text { usage. Additionally, as part of the F-GVEs product stewardship other GVEs may } \\
\text { be launched in order to provide after-sales services to the customer/market. }\end{array}$ \\
\hline
\end{tabular}


Table 3. R-GVE Detailed Lifecycle Stages [1] [6] [14] [15] [16]

\begin{tabular}{|c|c|c|}
\hline \multicolumn{2}{|r|}{ Lifecycle Stages } & Description \\
\hline \multirow{7}{*}{ 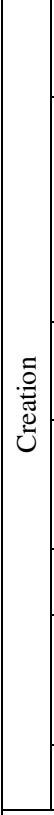 } & $\begin{array}{r}\text { Collaboration } \\
\text { Opportunity } \\
\text { Identification }\end{array}$ & $\begin{array}{l}\text { Identification of a collaboration (business) opportunity for a green product recall } \\
\text { based on a reverse logistics and an end-of-lifecycle manufacturing strategy. }\end{array}$ \\
\hline & $\begin{array}{r}\text { Collaboration } \\
\text { Opportunity } \\
\text { Characterisation }\end{array}$ & $\begin{array}{l}\text { Identification of the main features of the collaboration (business) opportunity, } \\
\text { including the green competency requirements and opportunity constrains for: } \\
\text { (a) product re-use - dealing with the direct-use of product components as spare } \\
\text { parts, (b) product re-manufacturing - dealing with the product for restoring } \\
\text { or rebuilding, (c) product recycling - dealing with the product for reclaiming } \\
\text { the valuable of its raw materials, or (d) product safe disposal - dealing with } \\
\text { the product hazardous wastes. }\end{array}$ \\
\hline & $\begin{array}{r}\text { Rough } \\
\text { Planning }\end{array}$ & $\begin{array}{l}\text { Identification of the required R-GVE partners competencies and capacities, } \\
\text { as well as the R-GVE possible configurations (supply network topologies) } \\
\text { to respond in a sustainable way to a collaboration (business) opportunity. }\end{array}$ \\
\hline & $\begin{array}{r}\text { Partners Search \& } \\
\text { Selection }\end{array}$ & $\begin{array}{l}\text { Identification of the potential R-GVE partners and their assessment and selection } \\
\text { based on their green degree. R-GVE partners will be evaluated based on their } \\
\text { green capabilities (receiving, separating, dismantling, sorting, testing) to handle } \\
\text { the end-of-life of a product. }\end{array}$ \\
\hline & Negotiation & $\begin{array}{l}\text { Interactive process to integrate the most suitable R-GVE partners in a dynamic } \\
\text { sustainable supply network to recover a green product from the market. }\end{array}$ \\
\hline & Detailed Planning & $\begin{array}{l}\text { Definition of the final R-GVE topology and its R-GVE partners' activities } \\
\text { schedule, including tasks assignments, budget allocation and green performance } \\
\text { indicators (end-of-life manufacturing, reverse logistics, hazardous wastes } \\
\text { management). }\end{array}$ \\
\hline & Contracting & $\begin{array}{l}\text { Formulation of the R-GVE contract, paying special attention to the environmental } \\
\text { regulations (laws, trades, taxes, fines). }\end{array}$ \\
\hline & Operation & $\begin{array}{l}\text { R-GVEs will operate following all sustainable principles in order to reduce } \\
\text { the environmental impact of their reverse logistics and end-of-life manufacturing } \\
\text { activities. }\end{array}$ \\
\hline & Evolution & $\begin{array}{l}\text { In case of unexpected events or disruptions during the R-GVE operation, } \\
\text { the R-GVE coordinator will re-configure and/or re-schedule the R-GVE partners } \\
\text { and their activities (tasks, budget) in order to try to keep the original end-of-life } \\
\text { manufacturing plan. }\end{array}$ \\
\hline & Dissolution & $\begin{array}{l}\text { As part of the GVBE industrial symbiosis strategy, any resource that could have } \\
\text { a secondary usage will be placed in the GVBE bag of assets for any possible } \\
\text { usage. Additionally, as part of the R-GVEs hazardous wastes management } \\
\text { activities, a specialised GVE may be tailored for their safe disposal. }\end{array}$ \\
\hline
\end{tabular}

dissolution will be placed in the GVBE bag of assets for its direct-use (re-use), repair, re-manufacture, recycle and/or safe disposal, and any output after a R-GVE dissolution will take two possible paths: to be returned immediately, if possible, as an input to active F-GVEs within the GVBE or will trigger a GVE formation specialised in hazardous wastes disposal.

\subsection{GVE Breeding Environment and Green Virtual Enterprises Technologies}

GVBEs supporting technologies (as concepts, methods or tools) [see 16 for more]:

Brokerage - Set of management activities and supporting tools that will support the identification of new collaboration (business) opportunities in the market that will trigger the formation of new GVEs and/or inside the GVBE that will lead to industrial symbiosis opportunities and/or collaborative investments (shareable infrastructures, joint purchases $>$ better negotiation power, joint promotion $>$ green marketing, etc.). 
Profiling and competency management - Set of management activities and supporting tools for creating and maintaining the GVBE and its members' profiles.

Partners search and selection - Set of management activities and supporting tools to identify, assess and select potential GVBE members and GVE partners.

Governance - Set of management activities and supporting tools that will facilitate any approach to collaboration (principles, rules, bylaws, values) and will guarantee the sustainability and correct behaviour/performance of all GVBE stakeholders.

Performance management - Set of management activities and supporting tools for planning and monitoring the GVBE strategies and rating and rewarding the GVBE actors' actions towards the GVBE goals achievement.

Bag of assets - Set of management activities and supporting tools to administrate a common virtual and physical warehouse to make easier the share of tangible and intangible assets between the GVBE members for different collaborative purposes [1].

Infrastructure management - Set of management activities and supporting tools for handling the GVBE infrastructures (ICT-based and physical-based) that will allow GVBE actors to interoperate and collaborate for different collaborative purposes.

GVEs management - Set of managing activities and supporting tools to manage the GVEs during its lifecycle [14] [15].

GVEs supporting technologies (as concepts, methods or tools):

Green product/service - refers to a product or service whose manufacturing or offering, purchase and use allows a sustainable economic development.

Green design - refers to a product or service design that puts special consideration into its environmental impact during its whole lifecycle.

Green materials - refers to a material that preserves natural resources and reduces the environmental impact, including those materials composed of recycled materials or can be recycled at the end of its lifespan.

Green processes - refers to a process that eliminates the environmental burden in its resources input, energy consumption, and outputs impact.

Green production - refers to a production system that puts a strong effort to lessen its environmental impact by conserving raw materials (using more recycled and/or renewable materials), minimising energy use and emissions, and wastes.

Green packaging - refers to the use of green materials in packaging, comprising recycled content, or reusable or degradable packaging materials to minimise landfill waste and transportation costs.

Green logistics - refers to any environmental friendly logistics strategy such as: commuting and shipping products together, using alternative fuel vehicles, reducing overall packaging, sharing warehouses and containers, etc.

Green recycling - refers to any of the 5R strategies: repair, re-manufacture, recycle, re-use or re-generated to reduce environmental impact.

\section{Conclusions and Further Research}

Defining a comprehensive reference model for GVBEs is a long-term endeavour, nevertheless based on the significant empirical knowledge (frameworks, models, concepts, methods and tools) and existing (eco-) industrial cases from the Industrial Ecology and Collaborative Networks scientific disciplines, it was realistic for the 
authors of this paper to try to design the first steps for a gradual definition of a "GVBE reference model". Future looks for sustainable industrial development models and current technological advances are leading to the formation of strategic alliances of enterprises that are geographically distributed, but work together to increase economic gains and minimise their environmental impact. Further research aims to work on a detailed model and management framework for GVEs and their breeding environments.

Acknowledgments. The research presented in this document is a contribution for the ECOLEAD Project (FP6 IP 506958), for the S-MC-S Project (FP7 NMP-ICT-FoF 260090), and for the ITESM, Campus MTY \& CCM, Research Chairs.

\section{References}

1. Romero, D., Molina, A.: Green Virtual Enterprises and their Breeding Environments. In: Camarinha-Matos, L.M., Boucher, X., Afsarmanesh, H. (eds.) PRO-VE 2010. IFIP AICT, vol. 336, pp. 25-35. Springer, Heidelberg (2010)

2. Srivastava, S.K.: Green Supply-Chain Management: A State-of-the-Art Literature Review. International Journal of Management Reviews 9(1), 53-80 (2007)

3. Camarinha-Matos, L.M.: Virtual Organizations in Manufacturing: Trends \& Challenges. In: 12th International Conference on Flexible Automation and Intelligent Manufacturing, pp. 1036-1054 (2002)

4. Camarinha-Matos, L.M., Afsarmanesh, H.: A Framework for VO Creation in a Breeding Environment. Annual Reviews in Control 31(1), 119-135 (2007)

5. Romero, D., Molina, A.: Virtual Organisation Breeding Environments Toolkit: Reference Model, Management Framework and Instantiation Methodology. Journal of Production Planning \& Control 21(2), 181-217 (2009)

6. Camarinha-Matos, L.M., et al.: A Framework for Computer-assisted Creation of Dynamic Virtual Organisations. International Journal of Production Research 47(17), 4661-4690 (2009)

7. Verdecho, M.J., Alfaro-Saiz, J.J., Rodríguez-Rodríguez, R.: An Approach to select Suppliers for Sustainable Collaborative Networks. In: Camarinha-Matos, L.M., Boucher, X., Afsarmanesh, H. (eds.) PRO-VE 2010. IFIP AICT, vol. 336, pp. 304-311. Springer, Heidelberg (2010)

8. Afsarmanesh, H., Camarinha-Matos, L.M.: A Framework for Management of Virtual Organization Breeding Environments. In: Camarinha-Matos, L.M., et al. (eds.) Collaborative Networks and their Breeding Environments, PRO-VE 2005. IFIP, pp. 35-48 (2005)

9. Camarinha-Matos, L.M., Afsarmanesh, H.: Collaborative Networks: Value Creation in a Knowledge Society. Knowledge Enterprise, IFIP 207, 26-40 (2006)

10. Chertow, M.R.: Industrial Symbiosis: Literature and Taxonomy. Annual Review of Energy and the Environment 25, 313-337 (2000)

11. Langley, J.: Seven Immutable Laws of Collaborative Logistics. NISTEVO Consulting (2000)

12. Ilgin, M.A., Gupta, S.M.: Environmentally Conscious Manufacturing and Product Recovery: A Review of the State of the Art. Journal of Environmental Management 91(3), 563-591 (2010) 
13. Cohen-Rosenthal, E.: Handbook on Codes, Covenants, Conditions \& Restrictions for EcoIndustrial Parks. Cornell Center for the Environment (1999)

14. Negretto, U., et al.: VO Management Solutions. Methods and Tools for Collaborative Networked Organizations, 257-274 (2008)

15. Karvonen, I., Salkari, L., Ollus, M.: Identification of Forms and Components of VO Inheritance. In: Camarinha-Matos, L.M., et al. (eds.) Foundation of Collaborative Networks, PRO-VE 2007. IFIP, vol. 243, pp. 253-262 (2007)

16. Romero, D., Molina, A.: VO Breeding Environments \& Virtual Organizations Integral Business Process Management Framework. Journal of Information Systems Frontiers 11(5), 569-597 (2009)

17. Chertow, M.R.: The Eco-Industrial Park Model Reconsidered. Journal of Industrial Ecology 2(3), 8-16 (1998) 